\title{
SELECTIVE ATTRACTION OF Vespula germanica (Hymenoptera: Vespidae) TO FEEDING BAITS ENHANCED WITH ISOBUTANOL AND ACETIC ACID
}

\author{
Tomislav Curkovic ${ }^{1 *}$, Javier Vergara ${ }^{1}$, Jaime E. Araya ${ }^{1}$, Américo Contreras ${ }^{2}$
}

${ }^{1}$ Depto. Sanidad Vegetal, Facultad de Ciencias Agronómicas, Universidad de Chile, Casilla 1004, Santiago, Chile.

${ }^{2}$ Dirección Escuela de Pregrado, Facultad de Ciencias Agronómicas, Universidad de Chile, Casilla 1004, Santiago, Chile

* Corresponding autor E-mail: tcurkovi@uchile.cl

\begin{abstract}
Vespula germanica (F.) has a negative impact on agriculture, beekeeping, and tourism in Chile. Therefore, environmentally-friendly strategies need to be implemented to control this serious pest. The objective of this study was to evaluate the response of adults of $V$. germanica to different types of baits with acetic acid + isobutanol (AAIB) added. The selected baits were: blood and bone flour (BF), raspberry jam (RJ), and sweet condensed milk (CM). The trial was conducted in a severely infested site in central Chile. Mixtures were placed in bottle traps. All of the traps were monitored daily from Monday to Friday during 5 weeks, and rebaited every week. A randomized complete block design, with 12 treatments and 4 replicates was used. Captures of V. germanica and other social hymenopterans were identified and data were recorded; $V$. germanica individuals approaching the trap openings (= visits) were also counted. A number of 15,480 V. germanica individuals, which were mostly workers, were captured. The most attractive baits were CM and BF $+2 \mathrm{~mL}$ AAIB. Feeding baits attracted significantly more workers with increasing concentrations of chemicals (AAIB), and significantly more wasps than the feeding baits alone. Lesser captures occurred of Apis mellifera workers $(1,046)$, while the preference trend differed from that observed for $V$. germanica in several treatments. A number of 854 Polistes buyssoni workers were captured, but no differences were found between treatments. In addition, a number of $466 \mathrm{~V}$. germanica visited the traps, but the trend observed with captures only occurred in traps baited with BF + AAIB, whereas no preference trend was observed for mixtures with RJ and CM. The results indicate that these attracting baits can be used not only to massively and selectively capture and destroy adults of $V$. germanica, but also to develop feeding baits not attractive for $A$. mellifera.
\end{abstract}

Key words: Apis mellifera, Polistes buyssoni, yellowjacket, baits, mass trapping, monitoring.

\section{INTRODUCTION}

The Vespidae family (Hymenoptera) includes 58 species in Chile (Willink and Chiappa, 1993), but several others have been either described or introduced during the last two decades in the country, reaching a number of 64 species (Chiappa et al., 2003; Barrera and Vidal, 2013; Barrera and Lukhaup, 2015). The German yellowjacket wasp, Vespula germanica (F.) (Hymenoptera: Vespidae), which is originally from Eurasia and northern Africa, has invaded New Zealand, Australia, South Africa, the US, Canada, Argentina, and Chile, due to shipping wood with mated queens (Sackman and Corley, 2007). It was introduced in Chile in the early 1970s (Peña et al., 1975), and has spread very rapidly as to be considered a pest (Chiappa et al., 1986; Estay et al., 2008). At present, it is found from Atacama $\left(\sim 27^{\circ} \mathrm{S}, 70^{\circ} \mathrm{W}\right)$ in the north to the Strait of Magellan and Tierra 
del Fuego Island $\left(\sim 54^{\circ} \mathrm{S}, 70^{\circ} \mathrm{W}\right)$, from sea level to $1800 \mathrm{~m}$ altitude (Estay et al., 2008; Sola et al., 2015).

This wasp has widely established and spread because it can live in different environments. In fact, it does not have significant natural enemies, preys with great voracity, and can feed from different food items, becoming a serious pest (Rizzuto, 2002; Estay et al., 2008). It causes damage to agriculture, especially in vineyards, reaching up to $10 \%$ losses in Chile in some years and areas (Curkovic et al., 2004; Ripa, 2004; Estay et al., 2008). In addition, Vespula germanica also affects apiaries (ODEPA, 2003), and tourism (Estay et al., 2008). Diverse strategies have been used to control this wasp worldwide. However, the use of sugary baits plus insecticides also affects honeybees, Apis mellifera L. (Hymenoptera: Apidae). Additionally, the use of animal protein (meat) alone or mixed with insecticides for immediate direct control of workers in order to reduce wasp density is more selective (Estay et al., 2008), but colonies are not completely controlled.

An efficient bait to trap and control $V$. germanica requires powerful, selective, and hopefully, specific attractants (Day and Jeanne 2001) to avoid affecting beneficial species, particularly honeybees and Bombus spp. (Estay et al., 2008). Besides, if those attractants are available, it is possible to prepare toxic baits (contaminated with insecticides) to affect the colony inside the nest. This might work well because of the trophalaxis behavior exhibited by Vespidae; workers provide larvae with protein, which mostly consists of chewed insects and spiders, or even meat of dead animals (Magunacelaya et al., 1986; Ripa, 2004), while larvae give them back sugary saliva in retribution, which is a rich source of energy that foragers need to fly and carry out body maintenance activities (Kasper et al., 2004).

Hymenopterans can detect volatiles by smell (Chapman, 2013). Vespids use them as cues for pollination (Brodmann et al., 2008), to find the nest (Jandt et al, 2005) or food sources (Day and Jeanne, 2001). Several volatiles are attractive and can orient $V$. germanica foragers to the source, including fruit odors and other chemicals (Landolt, 1998; Day and Jeanne, 2001). Preliminary trapping studies conducted in Chile by Correa (2005) reported low captures of $V$. germanica with sources of protein and some sugary foods alone, and found that the mixture of isobutanol + acetic acid was more attractive to foragers. These compounds have also proven attractive for Vespula spp. when mixed at certain rates (Landolt, 1998).

The objective of this study was to evaluate the attractiveness in the field of selected baits mixed with isobutanol + acetic acid at several concentrations to $V$. germanica and other eusocial Hymenoptera for the massive trapping of workers, and also as a first step for the future development of a toxic bait loaded with insecticides to control both adults and larvae inside the nest.

\section{MATERIALS AND METHODS}

Study site. The study was conducted in "Quebrada de la Plata" (3329' S; 7053 W), an 895 ha conservation area at "Rinconada de Maipú" Experimental Station, University of Chile, Metropolitan Region. Four sites located approx. 50-200 m apart were used. This is a wild and semi mountainous creek area (at $\sim 450$ m.a.s.l.), dominated by xeric shrub and sclerophytic trees, mainly Colliguaja odorifera (Gillies \& Hook), Acacia caven (Molina), Baccharis linearis [(Ruiz \& Pav.) Pers.], and Trevoa trinervis (Miers) (Gajardo, 1994). V. germanica has adequate developmental conditions in this area, including abundant prey, drinking water, and cellulose sources to build the nest and feed the colony. It has been reported that the establishment of this species has negatively affected beekeeping activities.

Feeding baits and chemicals. Feeding baits were selected to test attractiveness single or mixed with toxicants (attracticides) to $V$. germanica. The feeding baits evaluated were: blood and bone flour (BF), a by-product of the meat industry containing $20 \%$ protein, $22 \% \mathrm{Ca}$, and $11 \% \mathrm{P}$; sweet condensed milk (CM; 100 g provide 301 Kcal, $7.5 \mathrm{~g}$ protein, $4.1 \%$ fat, $58.7 \mathrm{~g}$ carbohydrates, $102 \mathrm{mg} \mathrm{Na}, 250 \mathrm{mg} \mathrm{Ca}$, and $190 \mathrm{~g} \mathrm{P}$ ); and raspberry jam (RJ; $100 \mathrm{~g}$ provide $247 \mathrm{Kcal}, 0.4$ $\mathrm{g}$ protein, $0.6 \%$ fat, and $60 \mathrm{~g}$ carbohydrates). BF was mixed with water $(10 \% \mathrm{w} / \mathrm{w})$ to keep the bait humid when exposed in the field. A volume of $\sim 26 \mathrm{~mL}$ of each feeding bait was used per trap. Besides, two chemicals were also added; a 1:1 mixture of acetic acid + isobutanol (AAIB) based on observations by Correa (2005). This author conducted a study with the same feeding baits evaluated here but with no addition of AAIB, and reported that they were not highly attractive under similar conditions in terms of location, vegetation, and season of the year. Mixtures were prepared immediately before placing the traps in the field. The amounts and combinations tested are presented in Table 1.

Traps and setting. Traps were $2 \mathrm{~L}$ transparent plastic bottles, with two $\sim 4 \mathrm{x} \sim 7 \mathrm{~cm}$ opposing openings (on the upper third). The $1 / 3$ bottom of each bottle contained a $5 \%$ solution of an odorless detergent to facilitate insect drowning. An 
Table 1. Feeding baits, chemical attractants, and volumes used/trap.

\begin{tabular}{lll}
\hline Abbreviations $^{1}$ & Food baits + chemical attractants & Volume $(\mathbf{m L})$ \\
\hline BF+AAIB3 & Blood and bone flour + acetic acid + isobutanol & $26+1+1$ \\
BF+AAIB2 & Blood and bone flour + acetic acid + isobutanol & $26+0.1+0.1$ \\
BF+AAIB1 & Blood and bone flour + acetic acid + isobutanol & $26+0.01+0.01$ \\
RJ+AAIB3 & Raspberry jam + acetic acid + isobutanol & $26+1+1$ \\
RJ+AAIB2 & Raspberry jam + acetic acid + isobutanol & $26+0.1+0.1$ \\
RJ+AAIB1 & Raspberry jam + acetic acid + isobutanol & $26+0.01+0.01$ \\
CM+AAIB3 & Condensed milk + acetic acid + isobutanol & $26+1+1$ \\
CM+AAIB2 & Condensed milk + acetic acid + isobutanol & $26+0.1+0.1$ \\
CM +AAIB1 & Condensed milk + acetic acid + isobutanol & $26+0.01+0.01$ \\
BF & Blood and bone flour & 26 \\
RJ & Raspberry jam & 26 \\
CM & Condensed milk & 26 \\
\hline
\end{tabular}

${ }^{1}$ BF: blood and bone flour; RJ: raspberry jam; CM: condensed milk

uncapped plastic vial $(\sim 30 \mathrm{~mL})$ was hung inside the bottle, placed between the trap openings, containing one of the bait treatments. The traps were set all the same day on trees and shrubs at the site, at $\sim 1.5 \mathrm{~m}$ above the ground. Vespula germanica density was not estimated by counting wasps/min entering/exiting the nest (as described by Harris, 1996), because nest entrances could not be found due to the dense shrubby vegetation in the area. Instead, the day before setting the experiment, the foragers flying in each place were roughly estimated, identifying a gradient in $V$. germanica population, from $\sim 1$ up to $\sim 10$ wasp/ min over the vegetation (in a $\sim 100 \mathrm{~m}$ transect in each plot), on the four sites (or blocks). Sites with greater densities were those closer to a small pound. Distance between traps was at least $20 \mathrm{~m}$ on each site, and they were set in open biological corridor areas.

Record keeping of captures and visits, and trap service. Field work was done Monday through Friday, starting at 9 AM every day, in February and March, a period of the year with maximum $V$. germanica activity in the region. Traps were rotated clockwise after each visit to minimize the effect of location within each block (Landolt, 1998). The number of visits (insects approaching a trap opening) was recorded during a 3-min period per trap with the observer at less than $1 \mathrm{~m}$ from the trap to identify the insect. Afterwards, social Hymenoptera were collected by sieving the detergent solution. The volume of detergent solution in the traps was $200 \mathrm{~mL}$. The baits were replaced each Friday. The study ended after two complete trap rotations within blocks.

Insect identification. Social Hymenoptera were collected in plastic bags, transported in a cooler to the Department of Crop Protection, College of Agronomic Sciences, University of Chile, and identified under magnification (20x). Only data on $V$. germanica (workers + males), and Polistes buysonni Brèthes and A. mellifera (workers) are presented. Insect identification on each visit was easy to perform in the field since $V$. germanica was the only Vespinae present in Chile in the area. $V$. vulgaris (L.) was reported to invade some areas in Chile $200 \mathrm{~km}$ to the south (Barrera and Vidal, 2013), and no other local Vespidae resembles the first.

Experimental design and data analysis. A randomized complete block design was used, with 12 treatments, 4 replicates, and 1 trap per experiment unit. Blocking was evaluated using the intraclass correlation coefficient (ICC) by estimating the variability within and between blocks (West et al., 2007). Captures and visits of individuals per trap were analyzed with a generalized linear mixed model, using the Poisson distribution and log link function through the lme4 package (Bates et al., 2015). The 12 treatments evaluated were included as a fixed effect on each block, nested within days, and evaluated as a random effect to verify the nonindependence of data. When overdispersion was detected, the experimental units were included in the model as a random effect, as suggested by Harrison (2014). Captures and visits with excessive zeros were analyzed with a zeroinflated Poisson model through the glmmADMB package (Fournier et al., 2012). Mean values per treatment were obtained through the application of the inverse link function of linear predictors, while standard errors were calculated through the Delta Method (Agresti, 2013). Significant differences between means were separated using 
the Tukey test for multiple comparisons through the lsmeans (Lenth, 2016) and multcompView (Graves et al., 2015) packages. All the analyses were done using the $\mathrm{R}$ programming language $(\mathrm{R}$ Core Team, 2016).

\section{RESULTS AND DISCUSSION}

All of the treatments captured adults of $V$. germanica, A. mellifera, and P. buyssoni (mean values adjusted to the model are presented in Table 2). No $V$. germanica queens were trapped. Visits in our study were $466 \mathrm{~V}$. germanica. The most captured species was $V$. germanica, with $89.1 \%$ (15,480 captures, mainly workers), while A. mellifera and P. buyssoni represented $6 \%(1,046)$ and $4.9 \%(854)$ of the samples, respectively.

Vespula germanica. Mean captures from treatments with the three types of baits and the highest AAIB concentration ( $2 \mathrm{~mL} /$ trap) were significantly greater than both food baits alone or the corresponding treatments with the lowest chemical loads (either 0.2 or $0.02 \mathrm{~mL} /$ trap, Table $2)$, thus highlighting the contribution of these volatile chemicals to yellowjacket attraction/ trapping. These results agree with those by Landolt (1998), Landolt et al. (1999), and Day and Jeanne (2001), who reported that increasing amounts of acetic acid + isobutanol (at 1:1, but not mixed with food baits) attracted more $V$. germanica and other yellowjacket wasps. Vapor pressure of the chemicals used are very high at the liquid stage (AA: $15.7 \mathrm{~mm} \mathrm{Hg}$ at $25^{\circ} \mathrm{C}$; IB: $9 \mathrm{~mm} \mathrm{Hg}$ at $20^{\circ} \mathrm{C}$, PUBCHEM, 2016), and evaporate quickly under field conditions (mean temperatures in February and March were $20-23^{\circ} \mathrm{C}$ at the site).

A study conducted by Landolt and Alfaro (2001) showed that AA evaporated at a rate of 8.2 $\mathrm{mg} \mathrm{h}^{-1}$, whereas IB did it at $10 \mathrm{mg} \mathrm{h}^{-1}$ (Landolt et al., 2005) from vials with small openings (1-3 mm), $\sim 10 \mathrm{x}$ smaller than those we used here. Mellado (2009) estimated that a similar load ( $2 \mathrm{~mL} /$ trap) of a 1:1 mixture of AA+IB mixed with food lasted up to $32 \mathrm{~h}$ in the field within a vial similar to that we used. Therefore, the differences observed in captures between the greatest and lowest volumes of the volatiles (AAIB) for each feeding bait might be related to the evaporation rate of AAIB loads in the vials, and their respective lasting attracting effect (shorter for smaller volumes). A similar conclusion was reached by Landolt et al. (2003) when using dispensing vials with larger diffusion rates of the attractants (but not mixed with food baits), that increased captures with time. We assume that larger release rates and attraction occur when larger initial loads of chemicals are tested. No significant differences were found between the intermediate and lower chemical loads. This suggests that their lasting period were both very short, resulting in no effect on captures giving the 1-3 d sampling intervals. On the other hand, when comparing the intermediate and lowest mixtures and the baits alone, only RJ at the intermediate AAIB load was significantly more attractive than RJ alone.

Attraction to CM and RJ baits is attributed to their carbohydrate content (particularly esters and sugars) that act as a reward for foraging wasps (Day and Jeanne, 2001). However, protein and fat

Table 2. V. germanica, A. mellifera, and P. buyssoni captures and visits (mean of individuals $\pm \mathrm{SE}$ ) in traps using different feeding baits and chemical concentrations (treatments).

\begin{tabular}{|c|c|c|c|c|}
\hline \multirow[t]{2}{*}{ Treatments } & \multicolumn{3}{|c|}{ Trap captures } & \multirow{2}{*}{$\begin{array}{l}\text { V. germanica } \\
\text { visits }\end{array}$} \\
\hline & V. germanica & A. mellifera & P. buyssoni & \\
\hline BF+AAIB3 & $12.6 \pm 3.3 \mathrm{a}$ & $0.30 \pm 0.10$ bcde & $0.64 \pm 0.51 \mathrm{a}$ & $0.79 \pm 0.17 \mathrm{a}$ \\
\hline CM+AAIB3 & $12.3 \pm 3.2 \mathrm{a}$ & $0.37 \pm 0.12$ abcde & $0.39 \pm 0.62 \mathrm{a}$ & $0.16 \pm 0.06 c$ \\
\hline RJ+AAIB3 & $9.0 \pm 2.4 \mathrm{ab}$ & $0.34 \pm 0.12$ abcde & $0.74 \pm 0.80 \mathrm{a}$ & $0.24 \pm 0.08 \mathrm{bc}$ \\
\hline CM+AAIB1 & $6.1 \pm 1.6 \mathrm{bc}$ & $0.58 \pm 0.17 \mathrm{abc}$ & $0.76 \pm 0.83 \mathrm{a}$ & $0.34 \pm 0.10 b c$ \\
\hline $\mathrm{CM}+\mathrm{AAIB} 2$ & $5.2 \pm 1.4 \mathrm{bcd}$ & $0.29 \pm 0.10 \mathrm{cde}$ & $0.46 \pm 0.65 a$ & $0.30 \pm 0.10 \mathrm{bc}$ \\
\hline BF+AAIB2 & $4.9 \pm 1.3 \mathrm{~cd}$ & $0.28 \pm 0.09$ cde & $0.32 \pm 0.60 \mathrm{a}$ & $0.53 \pm 0.15 \mathrm{ab}$ \\
\hline RJ+AAIB2 & $4.9 \pm 1.3 \mathrm{~cd}$ & $0.44 \pm 0.14 \mathrm{abcd}$ & $0.44 \pm 0.68 \mathrm{a}$ & $0.19 \pm 0.06 b c$ \\
\hline BF+AAIB1 & $4.5 \pm 1.2 \mathrm{~cd}$ & $0.26 \pm 0.09 \mathrm{de}$ & $0.91 \pm 0.95 \mathrm{a}$ & $0.34 \pm 0.10 b c$ \\
\hline RJ+AAIB1 & $3.9 \pm 1.1 \mathrm{cde}$ & $0.52 \pm 0.16 \mathrm{abcd}$ & $0.52 \pm 0.69 \mathrm{a}$ & $0.21 \pm 0.07 b c$ \\
\hline $\mathrm{CM}$ & $3.5 \pm 1.0$ cde & $0.62 \pm 0.19 \mathrm{ab}$ & $0.92 \pm 1.00 \mathrm{a}$ & $0.32 \pm 0.10 b c$ \\
\hline $\mathrm{BF}$ & $3.0 \pm 0.8 \mathrm{de}$ & $0.17 \pm 0.06 \mathrm{e}$ & $0.66 \pm 0.87 \mathrm{a}$ & $0.30 \pm 0.12 b c$ \\
\hline RM & $2.2 \pm 0.6 \mathrm{e}$ & $0.65 \pm 0.20 \mathrm{a}$ & $0.30 \pm 0.58 \mathrm{a}$ & $0.14 \pm 0.05 c$ \\
\hline
\end{tabular}

Means in a column with different letters are significantly different, according to Tukey test $(\mathrm{p}<0.05)$.

The ICC was 0.45 for $V$. germanica and 0.70 for A. mellifera. 
contents are much higher in CM than in RJ. This probably explains why $V$. germanica preferred the former bait, particularly because proteins are very important for brood production. Thus, these results might reveal a switching demand from carbohydrates to carbohydrates + proteins in workers, since both males and queens begin to be reared during that period (towards the end of the season) inside the nest, and workers must provide the colony with these nutrients to obtain the salivary reward from larvae (Kasper et al., 2004; Curkovic et al., 2004).

Considering the food baits alone, there was a trend for RJ to be less attractive to $V$. germanica workers, maybe due to its $\sim 10 x$ lower protein and fat content (despite its similarities in Kcal and sugar). BF attraction to workers is linked to the red meat volatiles (Spurr, 1995; D'Adamo et al., 2000). Workers of $V$. germanica have been found previously attracted to similar baits (but not including AAIB in the mixture) (Spurr, 1995; 1996). Unlike other reports (Day and Jeanne, 2001; Landolt, 1998; Landolt et al., 1999), in our study males were also captured (about $2 \%$ out of the total $V$. germanica captures) in baits that included AAIB.

\section{Apis mellifera, P. buysonni, and other} Hymenoptera. The number of individuals trapped was considerably less than yellowjackets, but enough for treatment discrimination of honeybees. There was a trend opposite to $V$. germanica results, since the bait with less honeybee captures was BF (either alone or mixed with AAIB), whereas the most attractive baits were $\mathrm{RM}$ and CM alone. Only $21.6 \%$ of the honeybee captures occurred on protein based baits. This discriminatory response points to the potential use of selective baits when the goal is to trap yellowjackets but not honeybees. The addition of chemicals (AAIB) caused less honeybee captures when mixed with the sugary food bait (again, just the opposite of yellowjacket captures) maybe because the chemicals acted as a repellent mixture, or because they affected the olfactory receptors or disrupted foraging A. mellifera before they reached the trap. Similar results have been published by Spurr (1996), who found that carbohydrates (including jam and condensed milk but not mixed with AAIB) were highly attractive for A. mellifera. These results may have been influenced by the vicinity of two apiaries. If that was the case, the honeybees collected seem very scarce if a productive hive holds many thousand workers. Discrimination between treatments was not obtained after statistical analysis for $P$. buyssoni (Table 2). No Bombus spp. were collected.
Visiting species. Only $V$. germanica presented relatively high visits, with significant differences of individuals approaching the traps between treatments, whereas other eusocial Hymenoptera (A. mellifera and P. buyssoni) were rarely observed. In general, results indicate significant visiting preferences of $V$. germanica for traps baited with BF with an increasing load of AAIB (Table 2), similar to what happened with captures. However, the trend was reverted for $\mathrm{CM}$, where the addition of increasing amounts of AAIB significantly reduced visits. Day and Jeanne (2001), on the other hand, found significantly more visits to fruit (pear) volatile extracts aged $24 \mathrm{~h}$, whereas fresh and $48 \mathrm{~h}$ aged extract were less attractive. It is important to have in mind that visits and captures where evaluated herein differently, visits during $3 \mathrm{~min}$, sometimes with totally fresh baits, whereas captures represent the responses from $V$. germanica to more aged baits overtime. It was not possible to model (and contrast) visits by P. buyssoni or A. mellifera, as over $90 \%$ of the traps had no visits during all the evaluation period.

\section{CONCLUSIONS}

The use of food baits (blood and bone flour $[\mathrm{BF}]$, condensed milk $[\mathrm{CM}]$, or raspberry jam [RJ]) plus increasing amounts of acetic acid (AA) + isobutanol (IB) at the source (up to $2 \mathrm{~mL}$ trap $^{-1}$ ), represents a better option to attract and capture $V$. germanica workers than the use of the food baits alone. BF and $\mathrm{CM}$ mixtures tended to perform better than RJ. On the other hand, Apis mellifera captures presented a relatively opposite trend, particularly for $\mathrm{CM}$, therefore suggesting the selective use of these baits to capture $V$. germanica, minimizing honeybee trapping. These results suggest to continue optimizing food baits for $V$. germanica control, for instance mixed with larger amounts of AAIB, during the spring and early summer to control populations before they reach maximum densities. It is also necessary to evaluate the actual impact from these treatments on the $V$. germanica density in treated areas.

\section{LITERATURE CITED}

Agresti, A. 2013. Categorical data analysis. 744 p. $3^{\text {rd }}$ ed. John Wiley \& Sons, Inc., Hoboken, New Jersey, USA.

Barrera, R., y C. Vidal. 2013. Primer reporte de Vespula vulgaris (Linnaeus, 1758) (Hymenoptera: Vespidae) en Chile. Bol. Soc. Ent. Aragonesa 52:277-278. 
Barrera, R., y C. Lukhaup. 2015. Eumenes Latreille, 1802 (Hymenoptera: Vespidae), un nuevo género para Chile. Bol. Soc. Ent. Aragonesa 56:309-311.

Bates, D., M. Maechler, B. Bolker, and S. Walker. 2015. Fitting linear mixed-effects models using lme4. J. Stat. Software 67(1):1-48.

Brodmann, J., R. Twele, W. Francke, G. Hölzler, Q.H. Zhang, and M. Ayasse. 2008. Orchids mimic green-leaf volatiles to attract preyhunting wasps for pollination. Current Biol. 18:740-744.

Chapman R.F. 2013. The insects: structure and function. 929 p. S.J. Simpson, A.E. Douglas (eds.). Cambridge University Press, Cambridge, UK.

Chiappa, E., J.C. Magunacelaya, y H. Jopia. 1986. Observaciones sobre el nido de Vespula germanica (Fab.) (Hymenoptera: Vespidae), en la zona central de Chile. Rev. Chil. Ent. 13:85-94

Chiappa, E., R. Ripa, y S. Rodríguez. 2003. Polybia ruficeps Schrottky, nueva especie social introducida a la $\mathrm{V}$ Región y primer registro de la tribu Epiponini (Hymenoptera, Vespidae, Polistinae) para Chile. Acta Entom. Chil. 27:67-71.

Correa, L. 2005. Evaluación de potenciales atrayentes de Vespula germanica (F.). 40 p. Memoria Ingeniero Agrónomo. Facultad de Ciencias Agronómicas, Universidad de Chile, Santiago, Chile.

Curkovic, T., J.E. Araya, y M.A. Guerrero. 2004. Avances en el manejo de la avispa chaqueta amarilla en Chile. Aconex 84:19-23.

D’ Adamo, P., P. Losada, and P. Sackmann. 2000. Local enhancement in the wasp Vespula germanica: are visual clues all that matter? Insectes Sociaux 47:281-289.

Day, S.E., and R.L. Jeanne. 2001. Food volatiles as attractants for yellowjackets (Hymenoptera: Vespidae). Env. Ent. 30:157-165.

Estay, P., R. Ripa, M. Gerding, J.E. Araya, y T. Curkovic, 2008. Manejo integrado de la avispa chaqueta amarilla Vespula germanica (Fabricius) (Hymenoptera: Vespidae). 74 p. Boletín INIA $\mathrm{N}^{\circ}$ 174. Instituto de Investigaciones Agropecuarias, Santiago, Chile,

Fournier, D.A., H.J. Skaug, J. Ancheta, J. Ianelli, A. Magnusson, M.N. Maunder, et al. 2012. AD Model Builder: using automatic differentiation for statistical inference of highly parameterized complex nonlinear models. Optim. Methods Softw. 27:233-249.

Gajardo, R. 1994. La vegetación natural de Chile, clasificación y distribución geográfica. 165 p. Editorial Universitaria, Santiago, Chile.
Graves, S., H.P. Piepho, L. Selzer, and D.R. Sundar. 2015. MultcompView: visualizations of paired comparisons. $\mathrm{R}$ package version 0.1-7. Available in: https:/CRAN.R-project. org/package=multcompView (Accessed 31 December 2015)

Harris, R.J. 1996. Frequency of overwintered Vespula germanica (Hymenoptera: Vespidae) colonies in scrubland-pasture habitat and their impact on prey. New Zeal J. Zool. 23:1117.

Harrison, X.A. 2014. Using observation-level random effects to model overdispersion in count data in ecology and evolution. PeerJ 2, e616. (doi:10.7717/peerj.616)

Jandt J. M., C. Curry, S. Hemauer, R.L. Jeanne. 2005. The accumulation of a chemical cue: nestentrance trail in the German yellowjacket, Vespula germanica. Naturwissenschaften 92:242-245.

Kasper M.L., A.F. Reeson, S.J.B. Cooper, K.D. Perry, and A.D. Austin. 2004. Assessment of prey overlap between a native (Polistes humilis) and an introduced (Vespula germanica) social wasp using morphology and phylogenetic analyses of $16 \mathrm{~S}$ rDNA. Molec. Ecol. 13:2037-2048.

Landolt, P.J. 1998. Chemical attractants for trapping yellowjackets Vespula germanica and Vespula pennsylvanica (Hymenoptera: Vespidae). Env. Ent. 27:1229-1234.

Landolt, P.J., and J.F. Alfaro. 2001. Trapping Lacanobia subjuncta, Xestia c-nigrum, and Mamestra configurata (Lepidoptera: Noctuidae) with acetic acid and 3-methyl1-butanol in controlled release dispensers. Env. Ent. 30:656-662.

Landolt, P.J., H.C. Reed, J.R. Aldrich, A.L. Antonelli, and C. Dickey. 1999. Social wasps (Hymenoptera: Vespidae) trapped with acetic acid and isobutanol. Florida Entomologist 82:609-614.

Landolt, P.J., H.C. Reed, and D. Ellis. 2003. Trappings yellowjackets (Hymenoptera: Vespidae) with heptyl butyrate emitted from controlled-release dispensers. Florida Entomologist 86:323-328.

Landolt, P.J., A. Pantoja, and D. Green. 2005. Yellowjacket wasps (Hymenoptera: Vespidae) trapped in Alaska with heptyl butyrate, acetic acid and isobutanol. J. Entomol. Soc. British Columbia 102:35-41.

Lenth, R. 2016. Least-squares means: The R package lsmeans. J. Stat. Software 69(1):1-33. 
Magunacelaya, J.C., E. Chiappa, H. Toro, y R. Jubal. 1986. Observaciones sobre comportamiento y alimentación de Vespula germanica (Hymenoptera: Vespidae) en la zona central de Chile. Rev. Chil. Entomol. 14:87-93.

Mellado, F. 2009. Evaluación de atrayentes sobre reinas y obreras de Vespula germanica (Fabr.) y otros insectos, en primavera, en la Quebrada de La Plata, Región Metropolitana. 39 p. Memoria Ingeniero Agrónomo. Facultad Ciencias Agronómicas, Universidad de Chile, Santiago, Chile.

ODEPA. 2003. Autoridades del agro coordinan acciones para combatir avispa chaqueta amarilla. Oficina de Estudios y Políticas Agrarias (ODEPA). Disponible en www.odepa.gob. cl/odepaweb/servlet/contenidos.ervletDetallesSer?idcla $=1 \&$ ideat $=2 \& i d n=1211$ (Consulta 02 noviembre 2016)

Peña, L.E., R. Pérez de Arce, y L. Cartagena. 1975. La presencia de Vespula maculifrons (Buysson) (Hymenoptera: Vespidae) en Chile. Rev. Chil. Entomol. 9:167-168.

PUBCHEM. 2016. Open Chemistry database.

National Center for Biotechnology

Information. USA. Available in https://

pubchem.ncbi.nlm.nih.gov/compound/

(Accessed 18 October 2016)

$\mathrm{R}$ Core Team. 2015. R: A language and environment for statistical computing. Vienna: $\mathrm{R}$ Foundation for Statistical Computing. Available in http://www.r-project.org/ (Accessed 02 November 2016).
Ripa, R. 2004. Vespula germanica: Chaqueta amarilla. Tierra Adentro 54:32-35.

Rizzuto, S. 2002. La avispa chaqueta amarilla (Vespula germanica). Biología y control en Esquel. Medio Ambiente 2:7-12.

Sackmann, P., and J.C. Corley. 2007. Control of Vespula germanica (Hymenoptera, Vespidae) populations using toxic baits: bait attractiveness and pesticide efficacy. J. Appl. Entomol., 131:630-636.

Sola, F., A. Valenzuela, C. Andersoni, G. Martínez, y M. Lencinas. 2015. Reciente invasión del Archipiélago de Tierra del Fuego por la avispa Vespula germanica (Hymenoptera: Vespidae). Rev. Soc. Entomol. Argent. 74:197-202.

Spurr, E.B. 1995. Protein bait preferences of wasps (Vespula vulgaris and V. germanica) at Mt Thomas, Canterbury, New Zealand. New Zeal. J. Zool. 22:281-289.

Spurr, E.B. 1996. Carbohydrate bait preferences of wasps (Vespula vulgaris and $V$. germanica) in New Zealand. New Zeal. J. Zool. 23:315-324.

West, B. Welch, K. and A. Galecki, 2007. Linear Mixed Model. A Practical Guide Using Statistical Software. 405 p. Chapman and Hall/CRC, Boca Raton, Florida, USA.

Willink, A., y E. Chiappa. 1993. Lista de las especies chilenas de la familia Vespidae (Hymenoptera: Vespidae). Acta Entomol. Chil. 18:119-125. 